\title{
Angling web forums as an additional tool for detection of new fish introductions: the first record of Perca fluviatilis in continental Portugal
}

\author{
F. Banha ${ }^{(1), \star}$, M. Ilhéu ${ }^{(2)}$, P.M. Anastácio ${ }^{(1)}$ \\ Received June 25, 2014 \\ Revised November 18, 2014 \\ Accepted December 6, 2014
}

\begin{abstract}
Key-words: $\quad$ This work reports for the first time the presence of a non-native fish, the Biological European Perch (Perca fluviatilis), in continental Portugal. The presence invasions, angling, freshwater introductions, invasive fish of this species was first reported on an angling web forum and its occurrence was scientifically confirmed later in a small reservoir of the Tagus river basin, located in the central region of Portugal. The importance of the angling web forums as a useful tool to help detection of non-native fish species introductions and their potential for education on biological invasions is discussed.
\end{abstract}

\section{ABSTRACT}

\section{RÉSUMÉ}

Les forums Internet de pêche à la ligne comme outil supplémentaire pour la détection de nouvelles introductions de poissons : le premier enregistrement de Perca fluviatilis au Portugal continental

\begin{abstract}
Mots-clés : $\quad$ Ce travail rapporte pour la première fois la présence d'un poisson non indigène, la Invasions perche européenne (Perca fluviatilis), au Portugal continental. La présence de cette biologiques, espèce a été signalée sur un forum web de pêche et son existence a été scientifipêche à la ligne, quement confirmée ensuite dans un petit réservoir du bassin du Tage, situé dans introductions en la région centrale du Portugal. L'importance des forums web de pêche à la ligne eaux douces, comme outil utile pour aider à la détection des introductions d'espèces non indipoisson envahissant gènes de poissons et son potentiel pour l'éducation sur les invasions biologiques est discutée.
\end{abstract}

The extremely rich endemic freshwater ichthyofauna of the Iberian Peninsula is facing a growing risk mainly due to habitat destruction and the introduction of non-native species. At least two-thirds of the freshwater and migratory fish species in Portugal and Spain are threatened, and in many river segments and lakes, non-native species are now dominant both in number and biomass. In the continental Portuguese freshwaters, eighteen non-native species are currently established, representing from $25 \%$ to $30 \%$ of the total fish community in several basins, mainly in the southern region (Ribeiro et al., 2009; Ilhéu, unpublished data). In Spain,

(1) IMAR - Centro de Mar e Ambiente / MARE, Departamento de Paisagem, Ambiente e Ordenamento, Escola de Ciências e Tecnologia, Universidade de Évora, Rua Romão Ramalho, no. 59, 7000-671 Évora, Portugal

(2) ICAAM - Instituto de Ciências Agrárias e Ambientais Mediterrânicas, Departamento de Paisagem, Ambiente e Ordenamento, Escola de Ciências e Tecnologia, Universidade de Évora, Rua Romão Ramalho, no. 59, 7000-671 Évora, Portugal

* Corresponding author: filipebanha@hotmail.com 


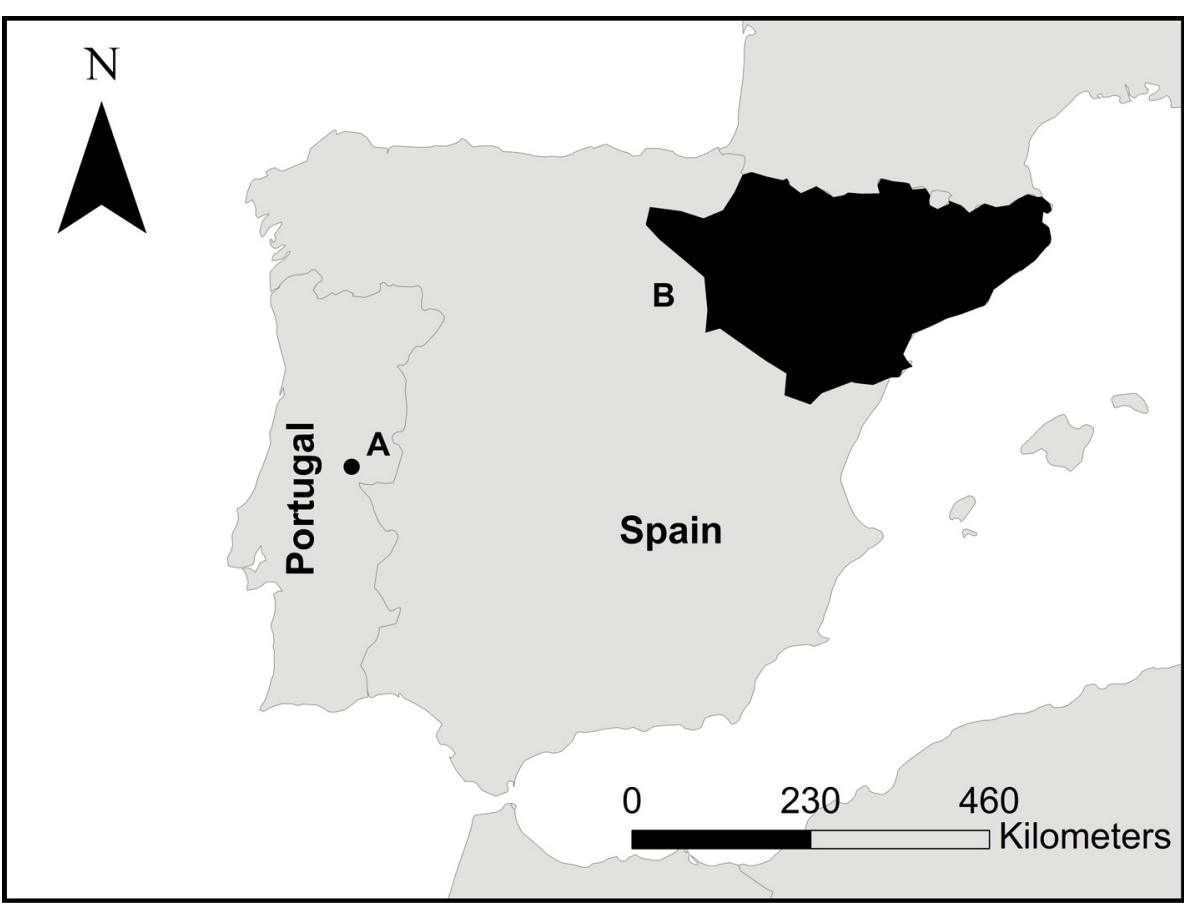

Figure 1

Perca fluviatilis distribution in the Iberian Peninsula. A- First record in Portugal, Vale longo reservoir in the Tagus river basin, reported in this work; $B$ - invaded area in Spain in the Ebro and Catalonian river basins.

twenty-six non-native fish species are currently established in freshwater ecosystems, representing at least $30 \%$ of the current freshwater fish fauna list (Elvira and Almodóvar, 2001; Leunda, 2010). The main routes or pathways for fish invasions in the Iberian Peninsula are well identified, being the entryway, the French border, with an invasion route from east to west, from Spain to Portugal. Most of these introductions occurred during the late 20th century and many of them were related to angling, including illegal stocking of target species and bait/"forage" species release.

The European perch, Perca fluviatilis (Linnaeus, 1758), is a medium-sized fish from the Percidae family. It is native to Europe and Siberia as far as the Kolyma River, being naturally absent from the Iberian Peninsula, Southern Italy and parts of the Balkan Peninsula. This species has a great capacity for adaptation to different environmental conditions and a high fecundity, being successfully introduced in several regions of the globe, including Oceania and Africa. In the Iberian Peninsula this species was introduced due to its sport value in the early 1970 s, its present distribution being mainly restricted to the vicinity of the French border, in the Catalonian river basins, including the Ebro river. This species has been successfully introduced into the Azores Islands (Ribeiro et al., 2009), but no previous report of the species occurrence has been made for Continental Portugal. This work aims to report the first occurrence of $P$. fluviatilis in inland Portuguese waters. Additionally, the importance of angling web forums as a useful tool to help detection of non-native fish species introductions and their potential for education on biological invasions is discussed.

A web search on the most visited and oldest Portuguese angling forum (http://www. portugalpesca.com, online since 2005; 5728 members; 261985 posts, accessed 18 August, 2013) was performed using the common name (in Portuguese) of non-native species present in Spain, but absent in Portugal, as keywords. After the analysis of the forum posts, including locations, photos and descriptions of the fish species, the report of $P$. fluviatilis catches ( 2 topics, 7 posts, 3 photos) was taken as potentially valid and field sampling was performed later on. The presence of $P$. fluviatilis in a small reservoir (Vale Longo; area $=3 \mathrm{ha}$ ) used for water supply by a conglomerate industry near Proença-a-Nova (Figure 1) was reported in the 
web forum from 2013. Two field surveys were conducted in this reservoir in February 2014. In the first one we assessed the reservoir conditions to select the fishing method, concluding the inefficiency of electrofishing due to the very deep (mean water depth $12 \mathrm{~m}$ ) and clear water, with low conductivity (value $103 \mu \mathrm{s} \cdot \mathrm{cm}^{-1}$ ). In the second one, a fishing rod was used with a small artificial lure technique. The session took $4 \mathrm{~h}$, before sunset and a mature male (sexually active) $P$. fluviatilis was captured. No other individuals from this or from other species were captured, but 2 other small $P$. fluviatilis individuals $(<10 \mathrm{~cm})$ were seen near the banks. The species identification was confirmed following Kottelat and Freyhof (2007) based on meristic features. The captured fish measured $17.2 \mathrm{~cm}$ standard length and presented $46.1 \mathrm{~g}$ of total weight. The specimen was transported alive in a bucket with water to the laboratory and preserved in $70 \%$ ethanol for future genetic analysis. During the field work, personal communications from three local fishermen revealed that this species is currently captured by anglers and its presence at this location dates from six to seven years ago. The gap between the date reported by the local fishermen (2007-2008) and the first post in the forum (2013) could be related to the reservoir's small size, low accessibility and number of fish species (Banha, unpublished data) and therefore its low attractiveness for anglers. The introduction of this species into continental Portugal nearly closes the list of potential predator fishes introduced primarily into Spain. We hypothesized that the long transport distance involved (more than $500 \mathrm{~km}$ ) between this Portuguese small reservoir and the nearest well-established population in Spain (in the Ebro river basin), which may have functioned as a donor region, may be associated with illegal transport of $P$. fluviatilis specimens by recreational fishermen. The Ebro basin has a great influx of anglers from all over Europe (Binimelis et al., 2007). As an example, 11 international largemouth bass boat fishing competitions have occurred in the Mequinenza reservoir (Ebro basin) since 1992 and Portuguese teams have always been present in this competition, with 12 participants per year (www.caspebass.com). Thus, P. fluviatilis (as well as other non-native species) can easily be transported alive in the livewell of modern fishing boats and this would be a likely process of transport. A possible reason for the introduction of $P$. fluviatilis into this particular reservoir may be related to the absence of other fish predator species in this water body (Banha, pers. observation), namely the non-native species Micropterus salmoides.

Since $P$. fluviatilis is apparently confined to this small reservoir, the Portuguese authorities (ICNF) were contacted so that an eradication plan could be started promptly. We propose lowering the water level of the reservoir, if possible reusing the water downstream, followed by selective electrofishing, with total removal of the individuals of this species and the rescue of native fishes. Additionally, a monitoring plan should be implemented to confirm the efficacy of the eradication plan during a 5-10-year period.

The first reported location of $P$. fluviatilis presence in Portugal is very close (less than $30 \mathrm{~km}$ ) to the location of the first record of wels catfish (Silurus glanis L.) in the Portuguese Tagus river basin. The Tagus river basin in Portugal presents one of the highest richnesses of non-native predatory fishes, with the occurrence of zander (Sander lucioperca L.), pike (Esox lucius L.), largemouth black bass (Micropterus salmoides Lacépède), wels catfish (Silurus glanis L.) and now $P$. fluviatilis. The anglers' preference for non-native game fishing, the availability of fishing guide services in the area and the influxes of fishermen may increase the introduction rate of non-native species in inland waters. The anglers' preference for non-native fish species may be related to the absence of native predatory or game fish species in the majority of the Portuguese river basins, particularly in the central and southern regions (Matono et al., 2012). In fact, native game fish species, namely the brown trout (Salmo trutta L.) and the Atlantic salmon (Salmo salar L.), are present mainly in the Northwest and in the mountain rivers of the Northern-Central region of Portugal (Cabral et al., 2005; Matono et al., 2012). Additionally, since the introduction of the largemouth black bass (Micropterus salmoides) in the 1950s, by the National Authority for Inland Fisheries (Ribeiro et al., 2009), the importance and popularity of predatory fish, as well as the number of recreational anglers, has increased considerably in the last few decades (Santos et al., 2006). Portuguese law (Decreto-Lei no. 565/99) forbids the introduction of non-native species; however, many illegal fish introductions have been taking 
place in the country, due to the lack of fishermen's awareness of biological invasion problems and inefficient control by the national authorities. Regrettably, Portuguese fishing law protects some of the oldest invasive species introduced (e.g. largemouth black bass) by applying minimum capture size and non-fishing periods (see http://www.icnf.pt/portal/pesca/pdesportiva/ calen-min). Fortunately, for the most recently introduced fish species these restrictions were not applied. In conclusion, anglers and environmental managers have conflicting interests. Non-native fish species recurrently introduced by anglers constitute a major concern and a great threat to native fauna through predation, competition, hybridization and transmission of new diseases to native fauna (see Leunda, 2010; EEA, 2012). For example, one of the most valued game fish species in Portugal, the non-native largemouth bass Micropterus salmoides, clearly affects the native fish community's structure (e.g. Godinho and Ferreira, 1998).

In Portugal, there are currently more than 11 active web angling forums dedicated to freshwater fishing activities, corresponding to more than 357000 users and 1700000 posts. In these forums there is information about fish species abundance, places of capture, methods of capture, baits, common names used, the sport and food value of each species, photos, methods used for illegal capture and even places suggested for future introductions. We found several fishermen's posts wishing for the spread of $P$. fluviatilis (4 posts), Rutilus rutilus (5 posts) and the introduction of other non-native species, namely Abramis sp. (4 posts). The information and reports posted on the angling forums are not rigorous but can be extremely useful for planning field sampling. New fish species reports in these forums should be considered reliable if the posts are numerous and from multiple authors and if these posts provide precise locations and good quality photos of the specimens. However, even reliable posts should be subjected to in situ scientific validation. Therefore, it is important to establish a link between the forums' administrators and the scientific community, environmental managers and the related government agencies, allowing a rapid response to the detection of new fish species. This partnership could be even more important or vital as a tool for invasive species awareness and environmental education, since the information easily reaches a great number of target people, preventing future introductions.

The information accessed in angling forums was already essential for Ribeiro and Veríssimo (2014), who published the first record of other non-native game fish in Portugal, namely the roach, Rutilus rutilus (Linnaeus, 1758). In Portugal, there is no specific sampling network exclusively for non-native species detection. This information is collected by a government agency (ICNF) from several diffuse sources (e.g. scientists' reports, fishing competitions supervised by ICNF, and EU Water Framework Directive data). Therefore, angling forums may provide additional information, complementing other sources and improving monitoring and action plans in the field of aquatic invasions.

\section{ACKNOWLEDGEMENTS}

F. Banha holds a PhD grant from FCT (SFRH/BD/81378/2011). This study was financed by the European Fund for Economic and Regional Development (FEDER) through the Program Operational Factors of Competitiveness (COMPETE) and National Funds through the Portuguese Foundation for Science and Technology (PEST-C/MAR/UI 0284/2011, FCOMP 01 0124 FEDER 022689).

\section{REFERENCES}

Aparicio E., Vargas M.J., Olmo J.M. and de Sostoa A., 2000. Decline of native freshwater fishes in a Mediterranean watershed on the Iberian Peninsula: a quantitative assessment. Environ. Biol. Fishes, 59, 11-19.

Benejam L., Carol J., Alcaraz C. and García-Berthou E., 2005. First record of the common bream (Abramis brama) introduced to the Iberian Peninsula. Limnetica, 24, 273-274. 
Bernardo J.M., Ilhéu M., Matono P. and Costa A.M., 2003. Interannual variation of fish assemblage structure in a Mediterranean river: implications of streamflow on the dominance of native exotic species. River Res. Appl., 19, 1-12.

Binimelis R., Monterroso I. and Rodríguez-Labajos B., 2007. A social analysis of the bioinvasions of Dreissena polymorpha in Spain and Hydrilla verticillata in Guatemala. Environ. Manag., 40, 555-566.

Cabral M.J., Almeida J., Almeida P.R., Dellinger T., Ferrand de Almeida N., Oliveira M., Palmeirim J., Queirós A., Rogado L. and Santos-Reis M., 2005. Livro vermelho dos vertebrados de Portugal. Instituto de Conservação da Natureza, Lisboa.

Clavero M. and García-Berthou E., 2006. Homogenization dynamics and introduction routes of invasive freshwater fish in the Iberian Peninsula. Ecol. Appl., 16, 2313-2324.

Doadrio I., 2001. Atlas y Libro Rojo de los Peces Continentales de España. Dirección General de Conservación de la Naturaleza, Madrid.

EEA, 2012. European Enviromental Agency. The impacts of invasive alien species in Europe. EEA Technical report, No. 16/2012, 10 p.

Elvira B. and Almodóvar A., 2001. Freshwater fish introductions in Spain: facts and figures at the beginning of the 21st century. J. Fish. Biol., 59, 323-331.

Elvira B., Almodóvar A. and Nicola G.G., 1998. Fish communities of the middle-upper Tagus river (central Spain): a story of river regulation and exotic introductions. Pol. Arch. Hydrobiol., 45, 165-171.

García-Berthou E. and Moreno-Amich R., 2000. Introduction of exotic fish into a Mediterranean lake over a 90-year period. Arch. Hydrobiol., 149, 271-284.

Godinho F.N. and Ferreira M.T., 1998. The relative influences of exotic species and environmental factors on an Iberian native fish community. Environ. Biol. Fish., 51, 41-51.

Hermoso V., Clavero M., Blanco-Garrido F. and Prenda J., 2011. Invasive species and habitat degradation in Iberian streams: an analysis of their role in freshwater fish diversity loss. Ecol. Appl., 21, 175-188.

Kottelat M. and Freyhof J., 2007. Handbook of European Freshwater Fishes. Kottelat, Cornol and Freyhof, Berlin.

Leunda P.M., 2010. Impacts of non-native fishes on lberian freshwater ichthyofauna: current knowledge and gaps. Aquat. Invas. , 5, 239-262.

Leunda P.M., Oscoz J. and Miranda R., 2006. Length-weight relationships of fishes from tributaries of the Ebro River, Spain. J. Appl. Ichthyol., 22, 299-300.

Matono P., Bernardo J., Ferreira M.T., Formigo N., Almeida P.R., Cortes R. and Ilhéu M., 2012. Fishbased groups for ecological assessment in rivers: the importance of environmental drivers on taxonomic and functional traits of fish Assemblages. Knowl. Manag. Aquat. Ecosyst, 405, 04.

Ribeiro F. and Veríssimo A., 2014. Full westward expansion of Rutilus rutilus (Linnaeus, 1758) in the Iberian Peninsula. J. Appl. Ichthyol., 1-3.

Ribeiro F., Collares-Pereira M.J. and Moyle P.B., 2009. Non-native fish in the fresh waters of Portugal, Azores and Madeira Islands: a growing threat to aquatic biodiversity. Fisheries Manag. Ecol., 16, 255-264.

Santos J.M., Ribeiro P.F., Gonçalves A.C. and Oliveira I., 2006. Análise Sócio-Económica da Pesca Desportiva In Estudo Estratégico para a Gestão das Pescas Continentais. PAMAF Medida 4 - IED, Acção 4.4 - Estudos Estratégicos, ICNF, Lisboa.

Thorpe J., 1977. Morphology, physiology, behavior, and ecology of Perca fluviatilis L. and P. flavescens Mitchill. J. Fish. Res. Board. Can., 34, 1504-1514.

Cite this article as: F. Banha, M. Ilhéu, P.M. Anastácio, 2015. Angling web forums as an additional tool for detection of new fish introductions: the first record of Perca fluviatilis in continental Portugal. Knowledge and Management of Aquatic Ecosystems, 416, 03. 